\title{
THE INFLUENCE OF THE BENEFIT REDISTRIBUTION METHOD ON THE WILLINGNESS TO VOLUNTARY CONTRIBUTE TO PUBLIC GOODS PROVISION - CLASSROOM EXPERIMENT
}

\author{
JANA PÉLIOVÁ ${ }^{1}$
}

\section{Vplyv spôsobu prerozdelenia úžitku na ochotu dobrovol'ne prispievat' na verejné statky - classroom experiment}

\begin{abstract}
Currently we are facing Covid 19 pandemics and it opens many questions about willingness of individuals to give up some private pleasure to contribute to public wellbeing. Theoretical economic research suggest that methodology of group account distribution does affect the contribution size. Lawyers, politicians and economists try to answer these questions using various scientific approaches and methods. One of them is to examine the willingness of individuals to contribute to public goods. Using a laboratory classroom experiment, we test various situations through public goods game. We examine whether economic entities are willing to contribute in situations when it is not advantageous for them from an individual point of view, but it is advantageous for society.
\end{abstract}

Key words: experiment, public good game, redistribution

JEL Classification: C92, H41

\footnotetext{
${ }^{1}$ doc. Ing. Jana Péliová, PhD., Ekonomická univerzita v Bratislave, Slovenská republika, e-mail: jana.
} peliova@euba.sk, ORCID ID: https://orcid.org/0000-0002-0305-0906 


\section{1 Úvod}

"Public goods and dilemma experiments are like using table-tennis balls; sensitive enough to be really informative but only with adequate control" - Experimenty na verejné statky a dilemy sú ako využivanie loptičiek pri stolnom tenise, dostatočne citlivé, aby boli zdrojom informácií, ale len vtedy, ak nad nimi máte kontrolu. (Ledyard, 1995, p. 115).

Pomerne často sa stretávame s problémom, že napriek zjavnej spoločenskej potrebe zabezpečovania tovarov alebo služieb vo verejnom záujme na ne jednotlivci nie sú ochotní prispievat'. Ak si predstavíme komunitu vel'kosti národného štátu a formu prispievania, napr. daň z príjmu, môžeme intuitívne čiastočne ospravedlnit' neochotu prispievatel'ov vzdialenost'ou k výslednému tovaru alebo službe. Ak však ide o menšie komunity, pre ktoré sú vzt'ah medzi príspevkom a zabezpečenou službou vel'mi jasné, očakávame vyššiu mieru kooperácie. Zmena ekonomických vzt'ahov prostredníctvom disrupcie ekonomiky čoraz viac nabáda $\mathrm{k}$ spoločnému/skupinovému zabezpečovaniu úžitkov pre menšie skupiny.

Tradičným nástrojom na meranie ochoty jednotlivcov prispievat' na spoločné blaho sú experimenty s verejnými statkami. ${ }^{2}$ Zároveň patria medzi najrozšírenejšie v oblasti ekonómie a experimentálnej psychológie, sociológie a politológie (kde sú známe aj ako experimenty na „sociálnu dilemu“). Ako vyplýva z citátu Johna Ledyarda, výsledky experimentov s verejnými statkami sú vel'mi citlivé na najmenšie detaily dizajnu, a práve preto predstavujú pre ekonómov výzvu.

Pomocou laboratórneho classroom experimentu na verejné statky otestujeme vplyv spôsobu prerozdelenia prostriedkov spoločného fondu a predchádzajúcej sociálnej blízkosti - na ochotu prispievat' na verejné statky. Získané výsledky otestujeme voči rozsiahlej výsledkovej základni tradičných experimentov na verejné statky. V d’alšom texte preto rozoberieme základné charakteristiky hry na verejný statok a dizajnu ekonomického experimentu na verejný statok. Predstavíme výsledky experimentu a porovnáme ich s empirickými očakávaniami o výške príspevku na verejné statky. V záverečnej časti sformulujeme odporúčania pre verejnú politiku.

\footnotetext{
${ }^{2} \mathrm{~V}$ teórii má verejný statok dve základné vlastnosti: a) je nerivalitný a b) nevylúčitel’ný zo spotreby. To znamená, že ked' sa statok alebo služba vyrobí (a) vel’a l’udí ho môže konzumovat' súčasne a (b) nemôžete prinútit' jednotlivcov, aby platili za to, čo konzumujú. Existuje niekol'ko príkladov verejných statkov, najčastejšie sa uvádza čistý vzduch, verejné parky, verejné zdravotníctvo, národná bezpečnost', verejný vedecký výskum atd’. Opakom verejných statkov je kolektívne zlo „public bads“, napríklad zločin, znečistenie a globálne otepl'ovanie.
} 


\section{Hra na verejný statok}

Zabezpečovanie verejných statkov spôsobuje zásadný problém: hoci sú prospešné pre všetkých, je v záujme každého jednotlivca byt' čiernym pasažierom a neprispievat' na ich výrobu. Tento konflikt môžeme jednoducho vysvetlit' pomocou tzv. väzňovej dilemy: predpokladajme, že existujú iba dvaja hráči, vy a iná osoba. Predpokladajme tiež, že môžeme uskutočnit' iba dve možné operácie: bud' spolupracovat' a prispiet' na verejný statok, alebo zradit' - neprispiet'. Odmeny v tejto hre musia spĺnat' nasledujúcu podmienku: zradit'/ spolupracovat' (ja zradím, ostatní spolupracujú) > spolupracovat'/spolupracovat' > zradit'/zradit' > spolupracovat'/zradit'. Bez ohl'adu na rozhodnutie druhého hráča ,zradit““ vždy generuje vyššiu odmenu ako „spolupracovat"“.

Z pohl'adu teórie hier je ,zradit"“ dominantnou stratégiou. Ak však všetci hráči hrajú dominantnú stratégiu, bude výsledok horší, ako by sa dalo dosiahnut', ak obaja spolupracujú. Individuálne racionálne konanie vedie v tomto prípade $\mathrm{k}$ neuspokojivému sociálnemu výsledku (výsledok je teda Pareto-inferiórny). Ak rozšírime počet hráčov hry na $\mathrm{N}$, môžeme na vysvetlenie použit' lineárnu hru s verejnými statkami. Základná podoba výplatnej funkcie lineárnej hry s verejným statkom je nasledujúca (Péliová, 2011):

$$
p_{i}=w_{i}-g_{i}+\beta_{i} \sum_{j=1}^{N} g_{j}
$$

$w i$ - úvodný vklad (initial endowment) i-tej osoby. Predstavuje disponibilný príjem jednotlivca, ktorý môže rozdelit’ medzi súkromnú spotrebu (Súkromný účet) a príspevok na zabezpečenie verejného statku (Spoločný účet) gi.

$g i$ - príspevok i-tej osoby na verejný statok. Rozdiel wi - gi predstavuje vlastnú, súkromnú spotrebu jednotlivca (príspevok na Súkromný účet).

$\beta i$ - príjem i-tej osoby z poskytovaného verejného statku. Túto hodnotu označujeme podl'a Isaaca a kol. (1984) ako hraničný príjem jednotlivca (Marginal per Capita Return - MPCR). Ak predpokladáme, že jednotlivec sa rozhoduje racionálne a maximalizuje svoj úžitok, potom sa MPCR rovná súčinu hraničnej miery substitúcie medzi verejným a súkromným statkom a hraničnej miery transformácie medzi týmito statkami. Rastúca hodnota tohto parametra vyjadruje klesajúcu cenu verejného statku v porovnaní so súkromným statkom. 
Ďalším predpokladom tohto modelu je, že celkový objem poskytovaných statkov sa odvíja od sumy vybraných príspevkov (verejné statky nemožno zabezpečovat' z prostriedkov získaných úverom). Množstvo poskytnutého verejného statku je preto rovné:

$$
G=\sum_{j=1}^{N} g_{j}
$$

Základnou podobou experimentu na verejné statky je jednoduchá investičná hra, v ktorej sa jednotlivec rozhoduje o rozdelení zvereného kapitálu (wi) bud' na súkromný účet alebo na spoločný účet. Ide o anonymnú a nekooperatívnu hru. V hre predstavuje Verejný statok Spoločný účet, ktorého podmienky investovania napínajú obe základné charakteristiky verejného statku. Každý jednotlivec v skupine získava rovnaký podiel zo spoločného účtu (nerivalitná spotreba). Na podiel zo spoločného účtu má nárok každý jednotlivec bez ohl'adu na to, či doň prispel alebo nie (nevylúčitel'nost' zo spotreby). Prístupov k určeniu faktorov, ktoré ovplyvňujú našu ochotu prispiet' na spoločný účet, je viacero.

Podl'a Croson (2010) spočíva najväčší a málo skúmaný rozdiel týkajúci sa hry na verejné statky v produkčnej funkcii. Teda v tom, akým spôsobom činnost' jednotlivca vplýva na tvorbu pozitívnych alebo negatívnych externalít pre ostatných. V prípade mechanizmu dobrovol'ného prispievania (VCM) vychádzame pri prijímaní rozhodnutí z dávania. Jednotlivci dostávajú úvodný vklad, ktorý môžu použit' na svoju súkromnú spotrebu alebo ho dat' na výrobu verejného statku. Ich príspevok na verejný statok vytvára v experimente hodnotu pre ostatných účastníkov (pozitívna externalita). Produkčná funkcia VCM hry je lineárna (preto sa niekedy nazýva aj lineárna hra s verejným statkom). Verejný úžitok rastie lineárne s rastom prostriedkov, ktorými prispejeme na verejný statok.

Iným typom je stanovenie produkčného prahu (Provision Point Mechanism - PPT). Aj pri tejto hre vychádzame pri rozhodovaní z dávania: Subjektom dáme úvodný vklad, ktorý môžu rozdelit’ na individuálnu spotrebu alebo na zaplatnenie verejného statku. Na rozdiel od VCM však PPM produkčná funkcia berie do úvahy prahovú hodnotu. Ak sa zhromaždí dostatok zdrojov, verejný statok sa vyprodukuje a všetci účastníci získajú svoj úžitok z verejného statku. Ak subjekty prispejú príliš málo zdrojov, verejný statok sa nevyrobí a nik neprofituje z pozitívnej externality. Prahová povaha tejto produkčnej funkcie má zásadné dôsledky pre určenie rovnováhy v tejto hre. Pri vhodných pa- 
rametroch stále existuje úplná rovnováha aj pri čiernom pasažierovi. Existuje však aj súbor efektívnych ekvilibrií, v ktorých je verejný statok poskytnutý, pričom každý jednotlivec prispieva čast'ou svojich nákladov.

Tretí typ produkčnej funkcie predstavuje hra spoločného fondu zdrojov (Common Pool Rresources - CPR). V tomto prípade sa rozhodujeme o tom, kol'ko zo spoločného fondu vezmeme. Napríklad jednotlivci môžu kosit' trávu na spoločnej lúke a mat' $\mathrm{z}$ toho úžitok. Tieto experimenty sa často opisujú ako hry, ktoré majú skôr negatívne externality na rozdiel od VCM alebo PPM. Produkčná funkcia v hrách CPR je zvyčajne nelineárna. Malé množstvo úrody vytvára pre jednotlivca väčší úžitok, ako je strata úžitku pre spoločenstvo (a je teda spoločensky efektívne). Čím viac však jednotlivec zužitkuje, tým nižší bude jeho dodatočný úžitok a väčšie náklady pre spoločnost', až kým spoločenské náklady neprevažujú nad súkromnými úžitkami (sociálne optimum). Vzhl'adom na rozsiahlost' problematiky sa v tomto článku zaoberáme iba lineárnou hrou na verejné statky.

\subsection{Faktory miery ochoty dobrovol’ne prispievat' na verejné statky}

Z hl'adiska faktorov, ktoré ovplyvňujú mieru dobrovol'ného prispievania na verejné statky a môžu byt' využité na porovnávanie konceptov a štruktúry designu, Chaudhuri (2010) vo svojej súbornej práci dopín̆a k trom skupinám faktorov, ktoré ovplyvňujú mieru dobrovol'ného prispievania podl'a Ledyarda (1995), a najmä trvalú spoluprácu v laboratóriu, aj fenomén podmienenej spolupráce:

1) faktory prostredia - ich vplyv na mieru prispievania je považovaný za experimentálne dokázatel'ný. Medzi faktory prostredia (tzv. silné vplyvy) môžeme zahrnút' premenné, ktoré definujú prostredie, $\mathrm{v}$ ktorom experiment prebieha. Sú to napríklad: počet účastníkov, pohlavie účastníkov, hraničný príjem na osobu, vnútorná miera výnosu, vonkajšia miera výnosu, anonymita, komunikácia, rozsah opakovania danej situácie.

2) systémové faktory - ich vplyv sa pri jednotlivých experimentoch odlišuje, alebo sa ich vplyv doposial' nepodarilo preukázat'. Túto skupinu faktorov tvoria systémové faktory, ktoré sú spojené s konkrétnym jedincom a do určitej miery sú dané aj jeho spoločenským statusom a rôznymi životnými skúsenost'ami. Môžeme sem zaradit' napríklad 
predsudky, ekonomické vzdelanie, skúsenost', identifikácia so skupinou, priatel'stvo, učenie sa, altruizmus, spravodlivost', úsilie, averzia $\mathrm{k}$ riziku.

3) faktory spojené s nastavením experimentu - ovplyvňujú inštitucionálnu podobu experimentu, resp. samotný mechanizmus poskytovania verejných statkov, pocit'ovanú mieru spravodlivosti, a môžu ovplyvnit' mieru výskytu javu čierneho pasažiera.

Faktory ovplyvňujúce trvalú spoluprácu pri hre na verejné statky v laboratóriu:

4) podmienená spolupráca - výška príspevku podmienených spolupracujúcich je pozitívne korelovaná bud's ich ex-ante očakávaniami o príspevkoch ostatných členov alebo ich skutočných príspevkoch.

5) vysoké monetárne tresty - napriek tomu, že vysoké peňažné tresty vedia zabezpečit' dlhodobú spoluprácu, zároveň otvárajú niekol'ko otázok: tieto tresty sú akoby d’alšou úrovňou verejných statkov, môžu pôsobit' anti-sociálne a môžu tiež viest' k nižšej efektívnosti oproti treatmentom bez trestu.

6) zabezpečenie spolupráce inými prostriedkami, ako sú tieto tresty môže íst' napríklad o nepeňažné represívne opatrenia ako vyjadrenie nesúhlasu alebo sociálneho vylúčenia, ale aj rada od predchádzajúcich generácií subjektov alebo selektívne párovanie subjektov s rovnakým nastavení mysle.

Vzhl'adom na hypotézu o vplyve sociálnej blízkosti na úroveň príspevkov môžeme konštatovat', že výsledky predchádzajúcich štúdií potvrdzujú pozitívny vplyv členov skupiny (v anglickej literatúre označovaných peers) na prosociálne správanie (Berger a Rodkin, 2012). Predpokladáme, že skutočnost' sociálnej blízkosti subjektov, ktorí sú členmi toho istého krúžku, bude pozitívne ovplyvňovat' ich prosociálne správanie (Van Hoorn, 2014) a vplývat' na vyššie príspevky na spoločný účet aj za cenu zníženia individuálneho úžitku.

Ďalšími faktormi, ktoré vplývajú na ochotu prispievat', je výška zvereného kapitálu/príjmu (manipulujeme jeho výškou vyjadrenou v experimentálnej mene) alebo efekt vlastníctva, ked' môžeme namiesto zvereného kapitálu umožnit' subjektom experimentu získat' príjem prostredníctvom vlastných rozhodnutí pri plnení rôznych úloh. S rozvojom poznania efektu poštuchnutia (nudge) dochádza aj k testovaniu rôznych prístupov k zobrazovaniu informá- 
cií súvisiacich s využitím prostriedkov z verejných fondov, najnižších resp. najvyšších príspevkov v skupine ako aj rámcovania týchto informácií.

Našou centrálnou otázkou je, ako ovplyvní zmena spôsobu prerozdelenia úžitkov zo spoločného účtu zloženého z dobrovol'ných príspevkov ochotu naň prispievat'. Komplementárnou otázkou je, či vzájomná sociálna blízkost' medzi členmi skupiny ovplyvňuje ochotu jednotlivcov zvýšit' výšku svojich príspevkov v lineárnej hre na verejné statky.

\section{Laboratórny classroom experiment na verejné statky}

$\mathrm{Na}$ testovanie vyššie uvedených faktorov využívame štandardný dizajn experimentu na verejné statky $\mathrm{v}$ snahe potvrdit' a replikovat' staršie závery a siet’ovú verziu VCM na poskytovanie verejných statkov vrátane mechanizmu reálneho času Kurzbana a kol. (2001) adaptovanú na podmienky clasroom experimentu podl’a Péliová (2011). Experiment pozostáva z 10 kôl. V každom kole dostane každý účastník $\mathrm{k}$ dispozícii 50 tokenov a informáciu, že počas experimentu sú účastníci náhodne rozdelení do dvoch skupín. Účastníci sa rozhodujú o rozdelení tokenov do jedného alebo do dvoch účtov, ktoré označujeme ako Súkromný účet a Skupinový účet. V každom kole získavajú sumu prostriedkov zo Súkromného účtu plus príjmy zo Skupinového účtu. Každý token, ktorý investujú na Súkromný účet, im prinesie zisk vo výške 1 \% z každého vloženého tokenu (jeden experimentálny cent). Suma tokenov vložená účastníkmi spoločne na Skupinový účet je multiplikovaná koeficientom 1,67 a celkový výnos je rozdelený medzi jednotlivých členov skupiny.

V prvých 3 kolách je výnos na Skupinovom účte rozdelený rovnomerne medzi všetkých členov skupiny (bez ohl'adu na výšku ich príspevku). V 4. a 5. kole sme stanovili produkčný prah a okrem pravidla o rovnomernom rozdelení príjmov zo Skupinového účtu sme pridali pravidlo, že príjmy na Skupinovom účte budú zúročené iba $\mathrm{v}$ prípade, ak celková suma na účte dosiahne alebo prevýši 20 tokenov. V prípade, že celkový výnos na Skupinovom účte nedosiahne produkčný prah 20 tokenov, peniaze budú presunuté na Súkromný účet jednotlivých členov skupiny, ktorý uskutočnili vklad. Tokeny umiestnené na Skupinový účet v 6. a v 7. kole sú po zúročení rozdelené medzi jednotlivých členov skupiny proporcionálne v závislosti od výšky ich vkladu na účet.

Subjekty uskutočňovali v prvých siedmich kolách simultánne rozhodnutia o výške svojho príspevku bez toho, aby mali informáciu o akomkol'vek príspe- 
vku ostatných členov svojej skupiny. V posledných troch kolách mali členovia skupiny informáciu o najnižšom alebo najvyššom príspevku v skupine a účastníci sa museli reagovat' na časový tlak. Rozhodujú o umiestnení 50 tokenov, ktoré získajú na začiatku kola ako úvodný vklad, na Súkromný a Spoločný účet, pričom jedno kolo trvá 45 sekúnd a časomiera na displeji ukazuje, kol'ko času zostáva do konca kola. Na Súkromný a Spoločný účet je pripísaný príspevok v takej výške, ktorú dosiahol ked’ časomiera ukázala čas 0 . Výnos Spoločného účtu je rovnomerne rozdelený medzi členov skupiny.

V ôsmom kole je na displeji znázornený vždy ten najnižší príspevok z pomedzi členov skupiny na Skupinový účet. Naopak, v 9. kole je na displeji znázornený najvyšší príspevok člena skupiny na Skupinový účet. Táto suma sa mení tak, ako sa v priebehu času menia príspevky členov skupiny.

V poslednom, 10. kole je na displeji znázornený najnižší príspevok člena skupiny na Skupinový účet. Zobrazená suma sa mení tak, ako sa v priebehu času menia príspevky členov skupiny. Zároveň platí, že prostriedky na Skupinovom účte budú zúročené iba $\mathrm{v}$ prípade, ak celkový vklad na účet bude vyšší ako 20 tokenov.

Obr. č. 1: Komunikačné okno pre účastníka hry na verejný statok

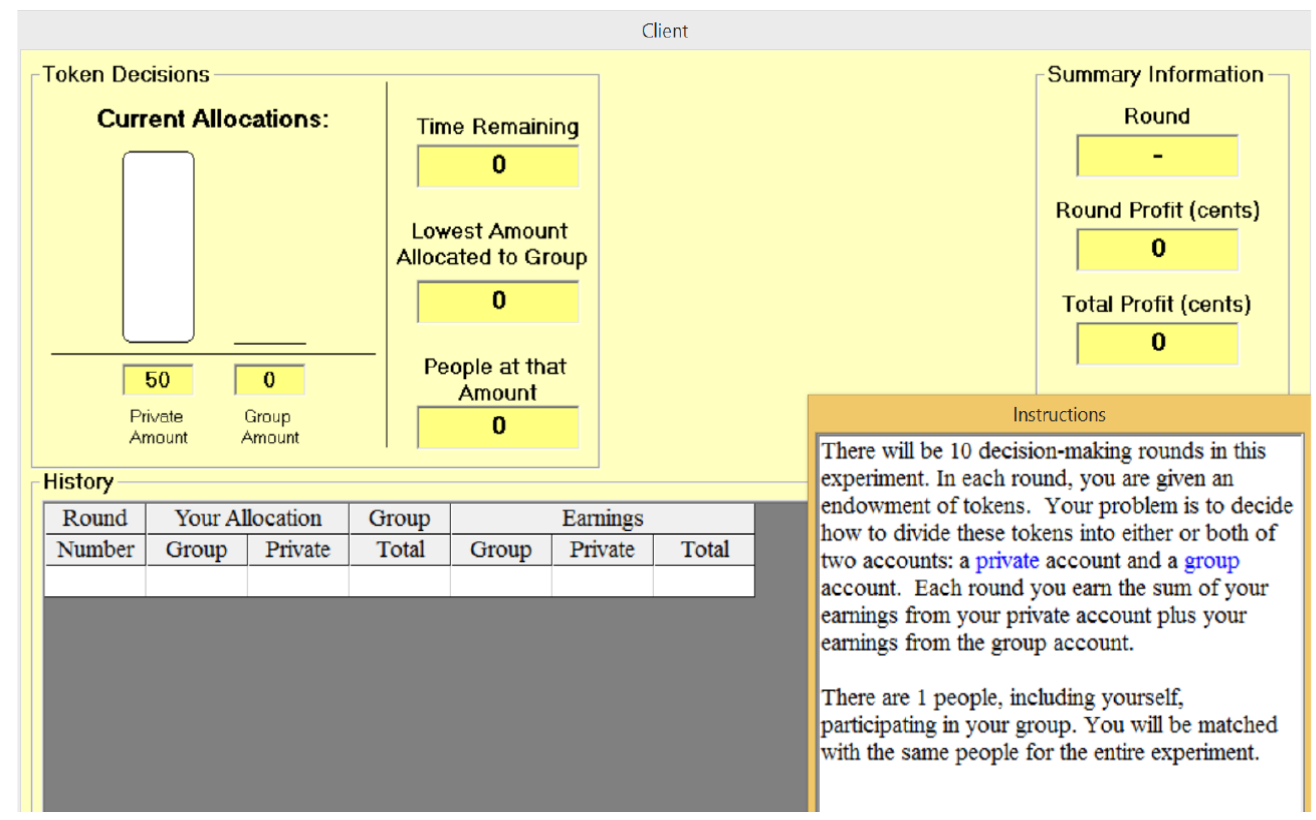

Zdroj: vlastné spracovanie autorky 


\section{Výsledky experimentu}

Experimentu sa zúčastnilo 28 subjektov, študentov zapísaných na predmet Experimentálna ekonómia. Príjmy získané počas experimentu boli prevedené na body, ktoré ovplyvnili celkový výsledok hodnotenia predmetu, aby sme dosiahli kontrolu nad motiváciou subjektov. Tento postup je zvyčajný pri tzv. classroom experimentoch. Priemerný príjem prepočítaný na experimentálne eurá bol 6,50. Subjekty boli náhodne rozdelené do 4 skupín po 7 subjektov v každej skupine.

Tabul'ka č. 1: Priemerný vklad na Spoločný účet

\begin{tabular}{|l|c|c|c|c|c|c|c|c|c|c|}
\hline Kolo & 1 & 2 & 3 & 4 & 5 & 6 & 7 & 8 & 9 & 10 \\
\hline Skupina 1 & 26,4 & 21,4 & 12,9 & 15,7 & 19,7 & 37,6 & 42,7 & 21,6 & 18,6 & 5,3 \\
\hline Skupina 2 & 18,6 & 23,6 & 29,3 & 21,4 & 15,6 & 20,6 & 20,3 & 21,7 & 28,9 & 15,0 \\
\hline Skupina 3 & 29,7 & 20,1 & 19,4 & 5,0 & 17,3 & 20,1 & 24,0 & 21,9 & 19,1 & 19,1 \\
\hline Skupina 4 & 21,6 & 25,9 & 17,6 & 16,6 & 18,6 & 16,7 & 24,3 & 23,3 & 12,3 & 12,9 \\
\hline Spolu & 24,1 & 22,8 & 19,8 & 14,7 & 17,8 & 23,8 & 27,8 & 22,1 & 19,7 & 13,1 \\
\hline
\end{tabular}

Zdroj: vlastné spracovanie autorky

Priemerné príspevky na Spoločný účet jednotlivých subjektov vo všetkých desiatich kolách sumarizuje tabul'ka č. 1. Vplyv spôsobu prerozdelenia príspevkov zo Spoločného účtu jednotlivým subjektom v prípade paralelných rozhodnutí predstavuje Graf č. 1. 
Graf č.1: Priemerný príspevok na Skupinový účet podl’a spôsobu prerozdelenia výnosu $(1-7$ kolo $)$

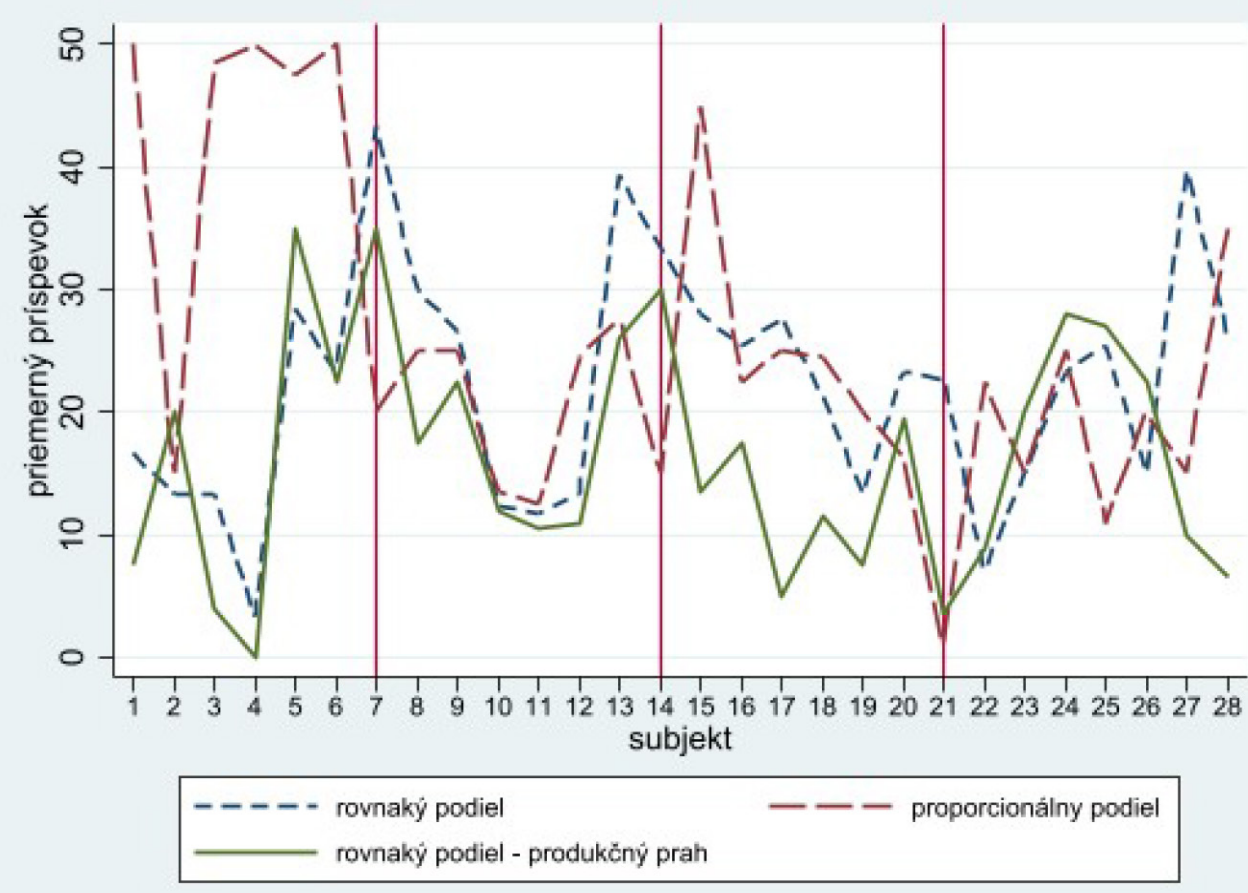

Zdroj: vlastné spracovanie autorky

Grafické zobrazenie priemerných príspevkov na spoločný účet v priebehu prvých siedmich kôl experimentu naznačuje zmeny v rozhodnutiach v závislosti od spôsobu prerozdelenia výnosu Spoločného účtu. V prvom kole bol najvyšší príspevok na Spoločný účet na úrovni 50 tokeov. V priebehu prvých troch kôl sa postupne väčšina príspevkov na Skupinový účet znížila na menej ako polovicu úvodného vkladu (50 tokenov) a v 3. kole už 5 účastníkov vložilo na Skupinový účet 0 tokenov. Tento jav môžeme označit' ako jav čierneho pasažiera. Subjekt neprispieva do Spoločného účtu, ale má rovnaký podiel na jeho výnose ako tí, ktorí na účet prostriedky vložili.

Zmena spôsobu výplaty prostriedkov zo Spoločného účtu z rovnakého na proporcionálny podl'a výšky realizovaných vkladov znamenala, že účastníci prispievali vo väčšom rozsahu a výška vkladov sa pohybovala v rozpätí 3050 tokenov. Na štatistickú analýzu vplyvu spôsobu prerozdelenia na výšku vkladu na Spoločný účet sme použili metódu tobit, vzhl'adom na to, že rozhodnutia o výške vkladu boli limitované úrovňou 0 až 50 tokenov, s využitím 
klastrovania na úrovni jednotlivých subjektov. Príspevky na Spoločný účet sa v závislosti od spôsobu prerozdelenia štatisticky významne neodlišujú, avšak výška príspevku závisí od jednotlivých skupín $(\mathrm{p}=0,072)$.

V kolách, ktoré obsahovali informáciu o úrovni (najnižšej a najvyššej) výšky vkladov ostatných členov skupiny boli rozhodnutia účastníkov ovplyvnené aj touto informáciou.

Ak boli účastníci experimentu informovaní o úrovni najnižšieho príspevku v skupine, bol najvyšší príspevok na Skupinový účet na úrovni 50 tokenov a najnižší na úrovni 0 tokenov, ako je zrejmé z Grafu č. 2., ktorý zaznamenáva na horizontálnej osi čas v sekundách a na vertikálnej osi výšku príspevku v tokenoch na Spoločný účet $\mathrm{v}$ danej sekunde. Priebeh zmien výšky príspevku v jednotlivých skupinách na Spoločný účet naznačuje, že príspevky v čase konvergujú, a sú teda ovplyvnené informáciou o najnižšom príspevku. Okrem jedného subjektu v prvej skupine, ktorý na spoločný účet neprispel, všetky ostatné subjekty svoje príspevky zvýšili. Informácia o výške najnižšieho príspevku v čase nespôsobila štatisticky významnú zmenu vo výške príspevku v porovnaní so simultánnym prispievaním v 1 . až 3. kole.

Graf č. 2: Príspevky na spoločný účet v 8. kole - informácia o najnižšom vklade

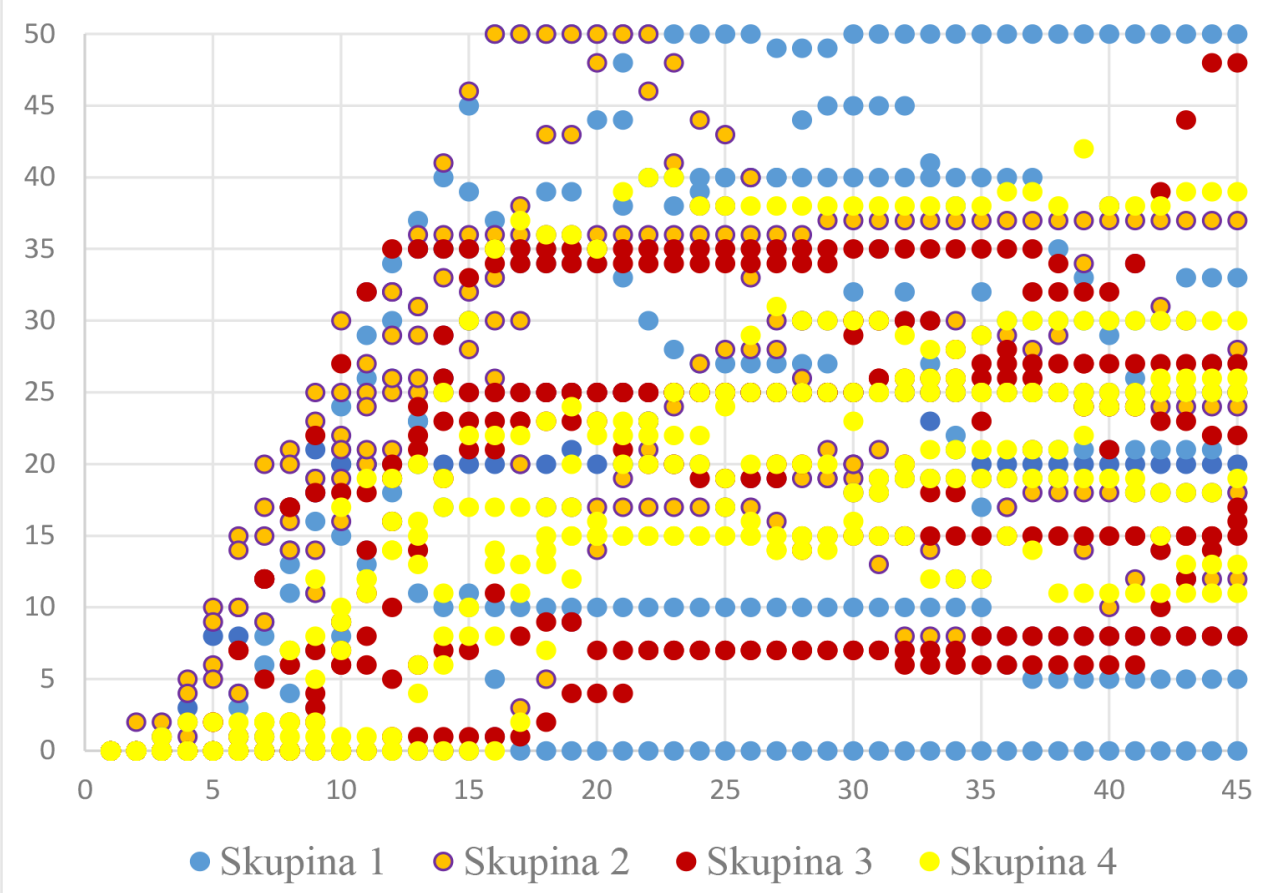

Zdroj: vlastné spracovanie autorky 
V súlade $\mathrm{s}$ teoretickými predpokladmi je priemerná úroveň vkladu na spoločný účet v prípade zverejnenia minimálneho vkladu (22,10 tokenu) oproti zverejneniu informácie o maximálnom vklade (19,71 tokenu). Vzhl'adom na vel'kost' vzorky sme však nepotvrdili štatistickú významnost' tohto rozdielu. Individuálne vklady na Spoločný účet v 9. kole zobrazené na Grafe č. 3 naznačujú významnú reakciu na zmenu nastavenia prostredia v skupine 3 a 4 . V tomto prípade zverejnenie výšky najvyššieho príspevku znamenalo výrazné zníženie vkladov (z priemerného vkladu 23,3 vo 8. kole na 13,3 tokenu v 9. kole).

Graf č. 3: Príspevky na spoločný účet v 9. kole - informácia o najvyššom vklade

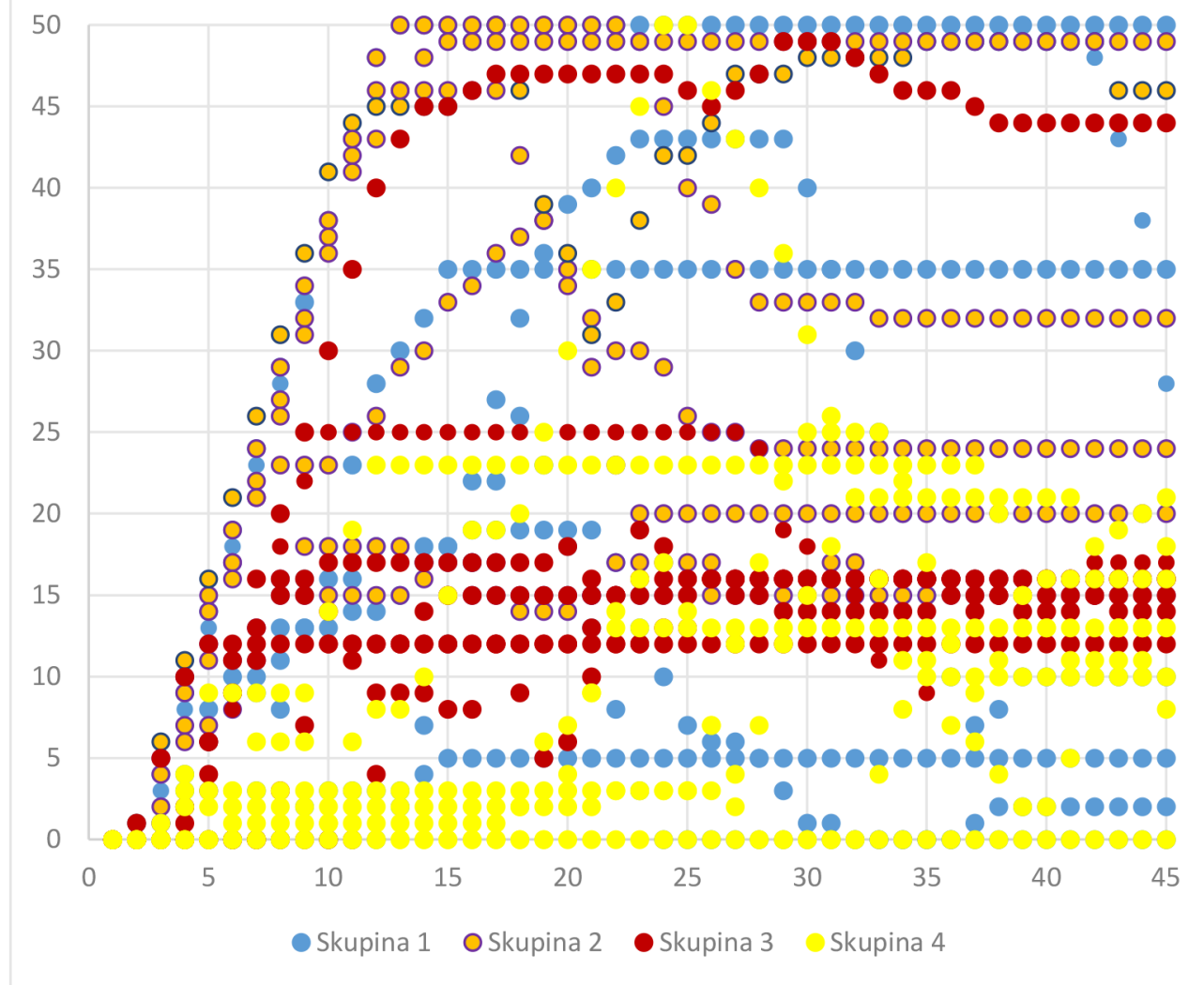

Zdroj: vlastné spracovanie autorky

Zavedenie produkčného prahu v 10 kole, súčasne so zverejnením informácie o najnižšom príspevku v skupine, znamenalo štatisticky významné $(p=0.0019)$ zníženie príspevku na Spoločný účet (zníženie z priemerného vkladu 22,1 vo 
8. kole na 13,07 tokenu v 10. kole). Tento výsledok nepotvrdzuje pozitívny vplyv zavedenia produkčného prahu na ochotu prispievat' na spoločný účet a je graficky znázornený na Grafe č. 4 .

Graf č. 4: Príspevky na spoločný účet v 10. kole - informácia o najnižšom vklade (produkčný prah

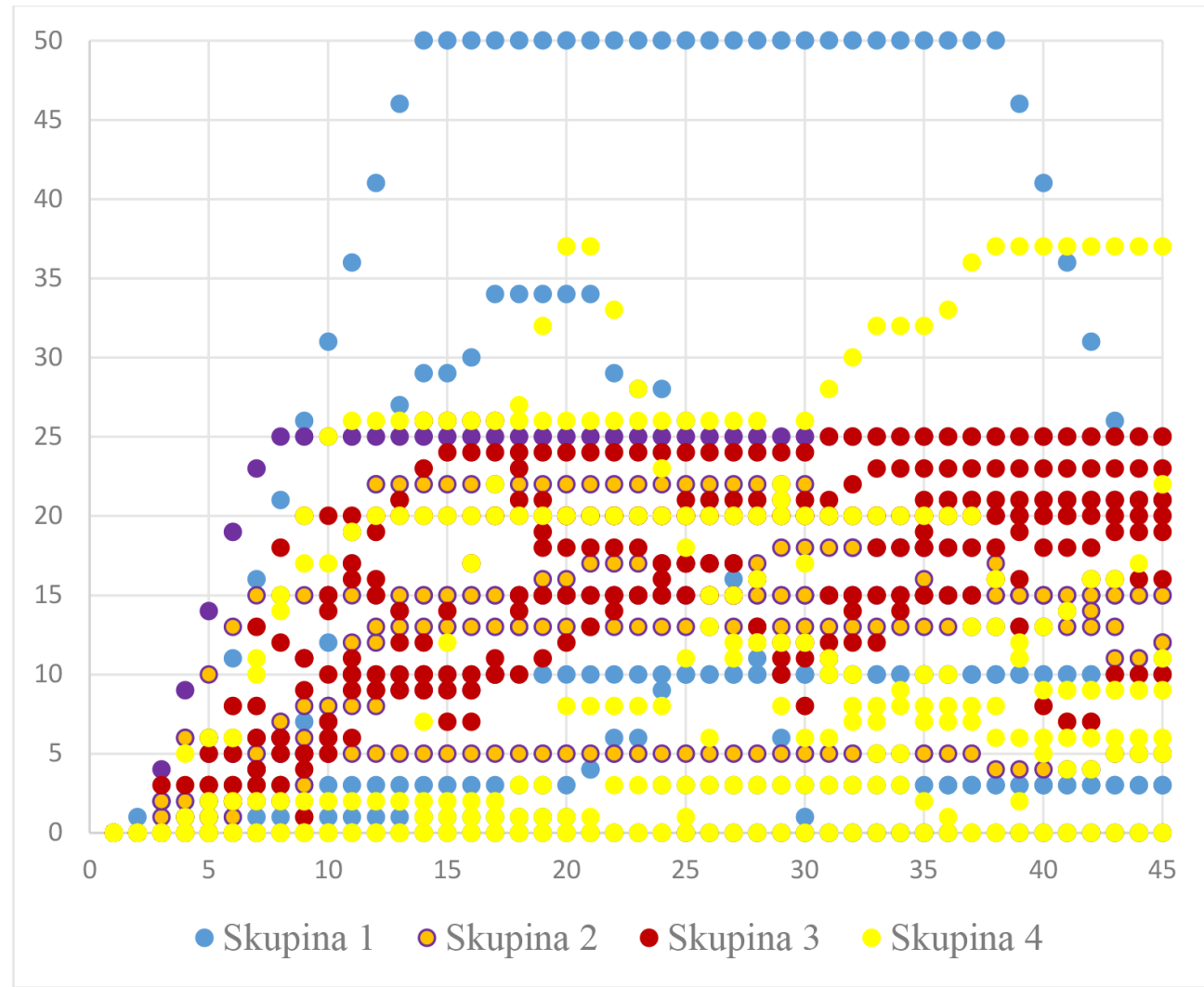

Zdroj: vlastné spracovanie autorky

\section{Diskusia a záver}

V reálnom živote je t’ažké odhalit' dôsledky zavádzaných nástrojov v tejto oblasti ex-ante, pretože našu ochotu prispievat' ovplyvňuje množstvo d'alších faktorov. Toto je dôvod, prečo sa využívanie laboratórnych experimentov javí ako vhodný nástroj.

Zhodne s teoretickými predpokladmi, výsledky experimentu preukázali závis- 
lost' ochoty subjektov prispievat' na verejné statky od spôsobu, akým je verejné blaho prerozdelené. Subjekty sú viac ochotné prispievat' na verejné statky v prípade, ak od toho závisí ich podiel na spotrebe spoločného blaha. Aplikáciou tohto záveru môže byt' využívanie niektorých daní na verejné statky, z ktorých benefitujú najmä ich daňovníci (napríklad daň z motorových vozidiel, daň za zber a likvidáciu odpadu).

Čiastočne sme potvrdili, že informácia o najnižšom vklade v skupine spôsobí zvýšenie priemerného vkladu z 19,8 v 3. kole na 22,1 tokena v 8. kole. Môžeme teda sformulovat' odporúčanie pre finančnú správu, že zverejňovanie zoznamov neplatičov by mohlo byt' použité ako jeden z nástrojov, ako zvýšit' ochotu platit' dane, a tak prispievat' na verejné statky. Pre potvrdenie tohto tvrdenia však treba experiment replikovat' na väčšej vzorke a s monetárnou motiváciou.

Hra na verejný statok je najviac použivanou štandardnou hrou. Na príklade uskutočneného laboratórneho experimentu sme prezentovali jednoduchý postup na jeho realizáciu, ktorý môže slúžit' v pedagogickom procese (môže byt' využitý pri výučbe problematiky verejných statkov, javu čierneho pasažiera a väzňovej dilemy), ale aj na overenie hypotéz vo výskume v oblasti verejných politík a pri skúmaní verejných statkov.

\section{Pod'akovanie}

Výskum je súčast'ou a financovaný z projektu VEGA 1/0827/18: Experimentálne skúmanie faktorov ovplyvňujúcich rozhodovanie ekonomických subjektov.

\section{LITERATÚRA}

[1] Berger, C., \& Rodkin, P. C. (2012). Group influences on individual aggression and prosociality: Early adolescents who change peer affiliations. Social Development, 21(2), 396 - 413. https://doi.org/10.1111/j.1467-9507.2011.00628.x

[2] Chaudhuri, A. (2010). Sustaining cooperation in laboratory public goods experiments: a selective survey of the literature. Experimental Economics, 14(1), $47-83$. https://doi.org/10.1007/s10683-010-9257-1 
[3] Croson, R.T.A. (2010). Public goods experiments. In: Durlauf S.N., Blume L.E. (eds) Behavioural and Experimental Economics. The New Palgrave Economics Collection. Palgrave Macmillan, London. https://doi.org/10.1057/9780230280786_28

[4] Isaac, R. M., Walker, J. M., \& Thomas, S. H. (1984). Divergent evidence on free riding: An experimental examination of possible explanations. Public choice, 43(2), 113 - 149. https://doi.org/10.1007/bf00140829

[5] Kurzban, R., McCabe, K., Smith, V. L., \& Wilson, B. J. (2001). Incremental commitment and reciprocity in a real-time public goods game. Personality and Social Psychology Bulletin, 27(12), 1662 - 1673. https://doi.org/10.1177/01461672012712009

[6] Ledyard, J. O. (1995). Public Goods: A Survey of Experimental Research. In: The Handbook of Experimental Economics. Princeton University Press, Princeton, pp. 111 $-194$.

[7] Péliová, J. (2011). Experiment v oblasti verejných statkov. In: Financie a riziko : zborník príspevkov z XIII. ročníka medzinárodnej vedeckej konferencie. Bratislava: Vydavatel'stvo EKONÓM, s. $142-148$.

[8] Van Hoorn, J., van Dijk, E., Meuwese, R., Rieffe, C., \& Crone, E. A. (2014). Peer influence on prosocial behavior in adolescence. Journal of Research on Adolescence, 26(1), $90-100$. https://doi.org/10.1111/jora.12173 